\title{
PENGENDALIAN PERSEDIAAN BARANG DAGANG MENGGUNAKAN METODE ECONOMIC ORDER QUANTITY
}

\author{
Fanny Andriani Setiawan'1, Margarita Ekadjaja², dan Yustina Peniyanti ${ }^{3}$ \\ ${ }^{1}$ Program Studi Akuntansi, Fakultas Ekonomi dan Bisnis Universitas Tarumanagara Jakarta \\ Email: fannys@fe.untar.ac.id \\ ${ }^{2}$ Program Studi Manajemen, Fakultas Ekonomi dan Bisnis Universitas Tarumanagara Jakarta \\ Email: margaritae@fe.untar.ac.id \\ ${ }^{3}$ Program Studi Akuntansi, Fakultas Ekonomi dan Bisnis Universitas Tarumanagara Jakarta \\ Email: yustinap@fe.untar.ac.id
}

\begin{abstract}
Inventory control can be done by reducing the cost of inventory and the number of ordering frequencies economically. PT Tanjung Globalindo Utama or Toko TODA is an oil and accessory retail store that provides various oil needs. Some of the problems are late delivery of goods from suppliers, so that for several days the company cannot operate optimally. On the other hand, the company has also experienced an excess inventory of merchandise, so the company wastes due to excess inventory of merchandise which in turn increases inventory costs. The Community Service Team (PKM) provides a solution for TODA Stores in overcoming their problems by providing training in inventory management in the Economic Order Quantity (EOQ) method. PKM activities were carried out on May 22, 2020. Participation of partners in the PKM program is to participate in discussions, provide historical data, and convey targets. The output is that the TODA Shop can determine the amount and schedule for the procurement of merchandise economically. The result is that Toko Toda begins to understand the importance of controlling inventory so that inventory costs are not too high. Proposed procedures for purchasing merchandise inventory were received and started to be carried out with monitoring from the relevant PKM Team. Based on the calculation simulation results and discussion shows that the use of the EOQ method in controlling merchandise inventory at Toda Stores is very efficient, seen from the amount of cost savings obtained if the total inventory cost calculation uses the EOQ method. Keywords: inventory, EOQ, ROP
\end{abstract}

\begin{abstract}
ABSTRAK
Pengendalian persediaan dapat dilakukan dengan menekan biaya persediaan dan jumlah frekwensi pemesanan secara ekonomis. PT Tanjung Globalindo Utama atau Toko TODA adalah Toko retail oli dan aksesori yang menyediakan berbagai kebutuhan oli. Beberapa permasalahan yang sering dialami adalah keterlambatan pengiriman barang dari supplier, sehingga selama beberapa hari perusahaan tidak dapat beroperasi maksimal. Disisi lain perusahaan juga pernah mengalami kelebihan persediaan barang dagang, sehingga perusahaan melakukan pemborosan akibat kelebihan persediaan barang dagang yang pada akhirnya meningkatkan biaya persediaan. Tim Pengabdian Kepada Masyarakat (PKM) memberikan solusi untuk Toko TODA dalam mengatasi permasalahannya dengan memberikan pelatihan tata kelola persediaan metode Economic Order Quantity (EOQ). Kegiatan PKM telah dilaksanakan pada tanggal 22 Mei 2020. Partisipasi mitra dalam program PKM adalah ikut serta dalam berdiskusi, memberikan data-data historikal, dan menyampaikan target yang hendak dicapai. Target luaran dari kegiatan PKM ini adalah Toko TODA dapat menentukan jumlah dan jadwal pengadaan barang dagang secara ekonomis. Hasil kegiatan PKM adalah Toko Toda mulai memahami pentingnya pengendalian persediaan barang dagang agar biaya persediaan tidak terlalu besar. Usulan prosedur pembelian persediaan barang dagang diterima dan mulai dijalankan dengan pemantauan dari Tim PKM terkait. Berdasarkan hasil simulasi perhitungan dan diskusi menunjukkan bahwa penggunaan metode EOQ dalam mengendalikan persediaan barang dagang pada Toko Toda sangatlah efisien terlihat dari besarnya penghematan biaya yang diperoleh jika perhitungan total biaya persediaan menggunakan metode $E O Q$.
\end{abstract}

Kata Kunci: Biaya persediaan, frekwensi pemesanan, economic order quantity

\section{PENDAHULUAN}

Dalam suatu aktifitas dagang suatu perusahaan diperlukan persediaan yang merupakan sejumlah barang yang dimiliki perusahaan untuk dijual dalam periode tertentu. Menurut Eugene F. Brigham and Joel F. Houston (2015), perencanaan dan pengendalian persediaan barang diperlukan untuk mengantisipasi pemenuhan permintaan pelanggan. Menurut Satria (2016) pengendalian 
persediaan diperlukan jika terjadi permintaan secara mendadak dan digunakan untuk mengidentifikasi jumlah barang dagang yang disimpan di gudang, dipakai dalam proses produksi kemudian dijual.

Secara umum, biaya sistem persediaan adalah semua biaya yang dikeluarkan maupun kerugian yang terjadi sebagai akibat adanya suatu persedian (Wahyudi, 2015). Dimana secara garis besar biaya persediaan ini dibagi dua yaitu biaya variabel dan biaya tetap. Menurut Wahyudi (2015), unsur-unsur biaya yang terdapat dalam persediaan meliputi :

a. Biaya Pengadaan

Biaya pengadaan merupakan biaya yang dibutuhkan atas ketersediaan suatu barang, meliputi biaya pemesanan (ordering cost) dan biaya pembuatan (set up cost).

Biaya pemesanan menunjukan besaran biaya yang dibutuhkan sehingga barang dagang tersebut tersedia di gudang. Besaran biaya pemesanan seperti biaya ekspedisi, biaya telepon, biaya suratmenyurat, biaya pengepakan dan penimbangan, upah, biaya pengiriman ke gudang, dan biaya pemeriksaan. Besarnya total biaya pemesanan barang dagang tidak tergantung banyaknya barang dagang yang dipesan, melainkan tergantung pada jumlah (frekwensi) pemesanan barang dagang tersebut.

Biaya pembuatan merupakan penjumlah semua pengeluaran dalam persiapan produksi suatu barang dagang. Beberapa hal yang menyebabkan terjadinya perubahan dalam biaya pembuatan antara lain: biaya peralatan produksi, biaya pemeliharaan mesin, biaya desain kerja, dan biaya untuk membeli suatu barang dagang.

\section{b. Biaya Penyimpanan (holding cost/ carrying cost)}

Biaya penyimpanan merupakan total biaya yang ada pada saat barang tersebut disimpan di gudang. Jika barang dagang yang tersimpan digudang terlalu banyak otomatis akan menambah besaran biaya simpan barang dagang tersebut. Bahkan apabila jumlah barang dagang tersebut terlalu banyak dapat menyebabkan terjadinya penumpukan persediaan barang dagang yang membuat gudang penuh dan perlu penambahan gudang baru. Hal ini dapat menyebabkan peningkatan biaya simpan dari persediaan barang dagang tersebut. Penambahan biaya simpan juga dapat berupa biaya keusangan, biaya asuransi, dan fasilitas penyimpanan yang harus tersedia dimana persediaan barang dagang tersebut memerlukan spesifikasi ruangan tertentu (seperti suhu ruang dan penerangan tertentu).

\section{c. Biaya Kekurangan Bahan (shortage cost)}

Biaya kekurangan bahan dapat meningkatkan total biaya persediaan barang dagang sebagai akibat persediaan barang dagang yang dipesan terjadi keterlambatan pengiriman sehingga ketersediaan barang dagang tersebut di gudang tidak tersedia. Hal ini dapat menyebabkan perusahaan tidak mampu memenuhi kebutuhan permintaan konsumen atas suatu barang dagang.

Dari pendapat di atas dapat disimpulkan bahwa suatu organisasi atau perusahaan dagang harus memiliki persediaan barang yang dapat memenuhi permintaan kebutuhan pelanggan. Satria (2016) mengidentifikasi beberapa faktor yang dijadikan sebagai fungsi perlunya persediaan meliputi :

waktu, ekspektasi yang akan datang dari supplier, adanya kebutuhan yang tiba-tiba, dan besarnya biaya yang dibutuhkan.

Menurut Tamodia (2013) pengendalian persediaan dapat dilakukan dengan menekan biaya persediaan dan jumlah pemesanan yang tepat ekonomis. Metode yang paling efektif dalam menekan biaya persediaan adalah dengan metode Economic Order Quantity (EOQ). Economic Order Quantity (EOQ) digunakan untuk mengukur biaya pemesanan persediaan barang yang 
paling ekonomis, dimana dalam metode Economic Order Quantity (EOQ) dilakukan pengukuran dalam pencapaian tingkat persediaan yang seminimum mungkin, biaya rendah dengan mutu yang jauh lebih baik.

Wardhani (2015) mengidentifikasi dengan adanya pengendalian barang dagang menggunakan metode Economic Order Quantity (EOQ), maka biaya kekurangan suatu barang dapat diminimalisir yang secara langsung mempengaruhi total dari biaya persediaan. Selain itu pengendalian barang dagang menggunakan metode Economic Order Quantity (EOQ) juga dapat mengurangi biaya penyimpanan dimana pemakaian ruangan lebih hemat sehingga gudang penyimpanan tidak perlu ditambah, dan terutama adanya pengurangan dari risiko penyimpanan barang yang menumpuk seperti kemungkinan barang yang disimpan rusak atau usang.

Menurut Yuliana \& Sudjana (2016) terdapat 4 metode untuk perhitungan meminimumkan biaya persediaan, yaitu :

a. Metode lot for lot

Tujuan dari metode lot for lot adalah menentukan rencana permintaaan dengan tepat pada setiap saat da memproduksi dengan tepat sesuai dengan kebutuhan tiap waktu sehingga menghilangkan biaya penyimpanan.

\section{b. Metode Economic Order Quantity (EOQ)}

Metode Economic Order Quantity (EOQ) digunakan untuk mengestimasi biaya penyimpanan dan biaya pemesanan.

c. Metode Least Total Cost (LTC)

Metode Least Total Cost (LTC) adalah metode dynamic lot-sizing dimana menentukan jumlah permintaan dengan membandingkan biaya simpan dan biaya pesan dengan varian biaya terkecil.

d. Metode Least Unit Cost (LUC)

Metode Least Unit Cost (LUC) adalah metode yang menentukan biaya per unit terkecil sehingga biaya simpan dan pesan menjadi kecil.

Metode Economic Order Quantity (EOQ) ini dapat digunakan dengan mudah dan praktis untuk merencanakan berapa kali suatu persediaan dibeli dan dalam kuantitas berapa kali pembelian. Menurut Brigham and Houston (2016) beberapa asumsi pengendalian barang dagang menggunakan metode EOQ : (1) Permintaan barang dagang rata-rata sifatnya seragam dan terus menerus stabil jumlahnya. (2) Waktu tunggu (lead time) yang merupakan waktu sejak pemesanan sampai barang dagang tersebut disimpan di gudang. (3) Barang dagang yang dipesan bersifat individu yang tidak mempengaruhi besarnya persediaan barang dagang lainnya. (4) Besaran biaya pengadaan barang yang meliputi harga pada saat pembelian, biaya pengiriman dan biaya simpan diketahui dengan pasti. (5) Jumlah pemesanan barang, variasi barang, dan ketersediaan barang dagang diketahui dan sifatnya konstan.

Menurut Muryanti, Y. D. (2017) tujuan pengendalian persediaan barang dagang adalah untuk mengetahui jumlah persediaan barang dagang yang tersedia saat barang tersebut dibutuhkan saat jumlah persediaan barang dagang mencapai titik minimum.

PT Tanjung Globalindo Utama atau yang lebih dikenal Toko TODA adalah Toko retail oli dan aksesori yang menyediakan berbagai kebutuhan oli. Di antaranya adalah aneka produk yang lengkap, mulai dari racikan lokal hingga impor. Beberapa produk dari Pertamina, Top1, Gulf, Shell, Motorex, dan masih banyak lainnya. Oli motor sendiri juga terbilang bervariasi, mulai dari jenis bebek, skutik, genre sport, genre naked bike, hingga moge dengan kapasitas mesin di atas 1.000 cc. 
Pelanggan Toko TODA cukup banyak dikarenakan barang yang dijual cukup bervariasi. Selain itu keunggulan lainnya adalah pelanggan akan mendapat penjelasan detail speksifikasi oli motor yang diinginkan, baik lokal maupun impor. semua pramuniaga yang siap melayani pelanggan dilatih terlebih dahulu sehingga sangat profesional menjelaskan volume oli yang dibutuhkan serta ulasan spesifikasinya. Selain itu pengunjung juga bisa mendapatkan edukasi mengenai jenis oli, baik bahan full sintetis, maupun semi-sintetis termasuk nilai viskositas oli yang dibutuhkan sesuai jenis kendaraan dan iklim. Agar penjualan perusahaan stabil, maka perlu adanya perencanaan dan pengendalian persediaan barang dagang.

Beberapa permasalahan yang sering dialami adalah keterlambatan pengiriman barang dari supplier, sehingga selama beberapa hari perusahaan tidak dapat beroperasi maksimal. Disisi lain perusahaan juga pernah mengalami kelebihan persediaan barang dagang, sehingga perusahaan melakukan pemborosan akibat kelebihan persediaan yang dilakukan karena menambah biaya penyimpanan persediaan di gudang.

Selama ini Toko TODA dalam melaksanakan kegiatan pengadaan persediaan barang dagang dengan frekwensi pembelian setiap 6 bulan sekali. Pembelian bahan barang dagang Toko TODA dilakukan pada awal bulan. Dikarenakan untuk mengantisipasi keterlambatan pengiriman persediaan barang dagang dari supplier menyebabkan seringkali Toko TODA menambah persediaan barang dagang terlampau banyak. Hal ini membuat tingginya biaya total persediaan barang dagang Toko TODA. Ketepatan dalam pengendalian persediaan barang dagang terkait dengan frekuensi pembelian dan kuantitas barang dagang, sehingga akan tercapai efisiensi persediaan barang dagang. Untuk mendukung tercapainya ketepatan tersebut Toko TODA harus menghitung Economic Order Quantity (EOQ) guna menekan biaya persediaannya.
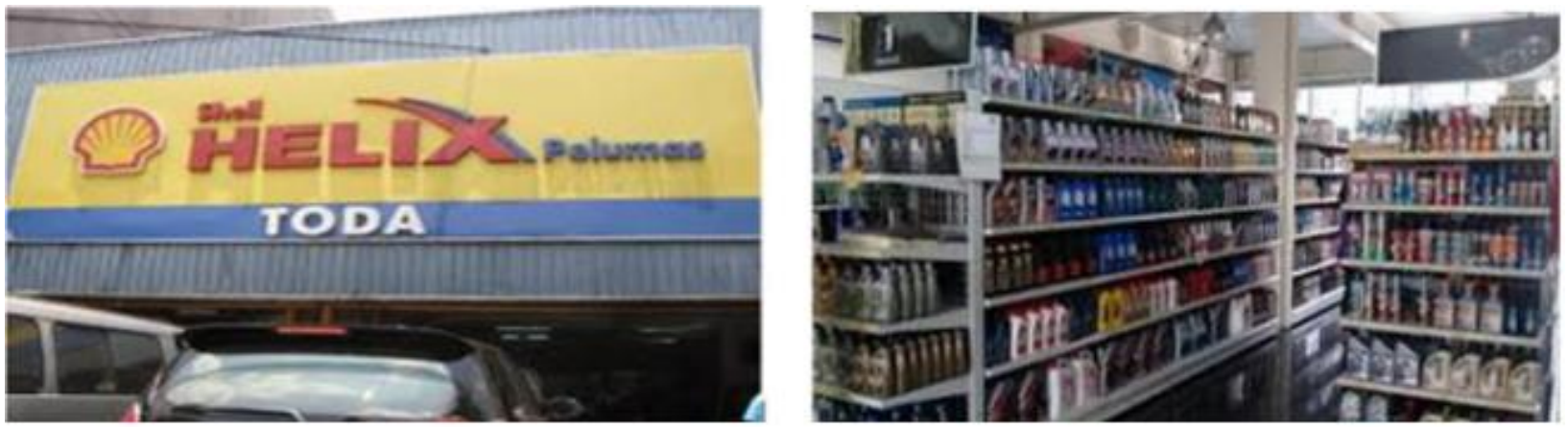

Gambar 1. Toko TODA

Sumber : Penulis, 2020

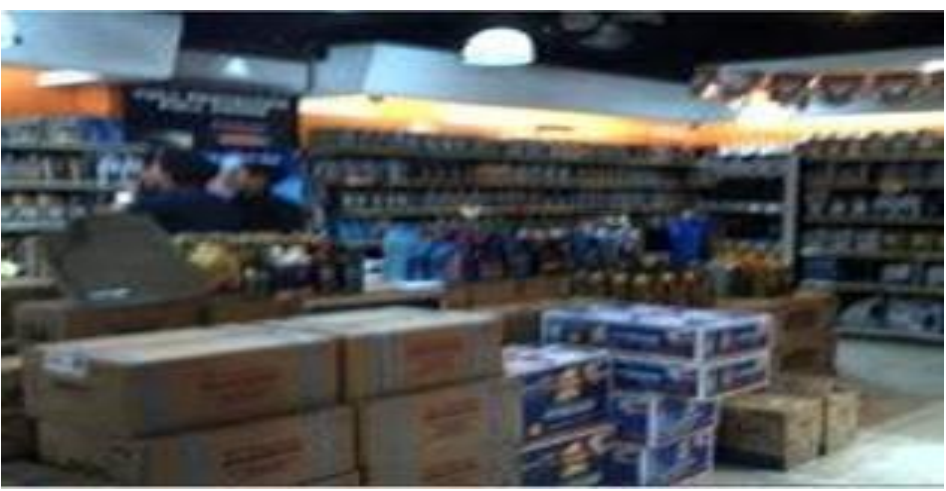

Gambar 2. Penumpukan persediaan barang dagang Sumber : Penulis, 2020 
Gambar 1 merupakan Toko TODA yang berada di daerah Kelapa Gading yang merupakan cabang ke empat. Barang dagang yang dijual adalah oli yang bervariasi, sehingga banyak pelanggan yang menganggap bahwa Toko TODA merupakan supermarketnya pelumnas seperti oli

Pada Gambar 2. menunjukkan adanya penumpukan persediaan barang dagang karena pembelian persediaan barang dagang yang terlalu banyak sehingga gudang tidak mencukupi hal tersebut yang menyebabkan tingginya biaya persediaan dari tahun ke tahun.

Permasalahan utama Toko TODA adalah adanya keterlambatan pengiriman barang dari supplier, sehingga selama beberapa hari perusahaan tidak dapat beroperasi maksimal. Disisi lain perusahaan juga pernah mengalami kelebihan persediaan barang dagang, sehingga perusahaan melakukan pemborosan akibat kelebihan persediaan yang dilakukan karena menambah biaya penyimpanan persediaan di gudang.

Tim Pengabdian Kepada Masyarakat (PKM) memberikan solusi untuk Toko TODA dalam mengatasi permasalahannya melalui pelatihan. Tujuan umum dari pelatihan adalah membantu UMKM Toko TODA sebagai masukan yang mungkin dapat digunakan untuk membantu perusahaan untuk dapat menjaga keseimbangan antara keseimbangan besarnya modal dan biaya yang dibutuhkan untuk mengadakan persediaan barang dagang. Tujuan khusus dari pelatihan adalah mengetahui apakah metode Economic Order Quantity (EOQ) dapat meminimumkan biaya persediaan.

\section{METODE PELAKSANAAN PKM}

\section{Tahapan Kegiatan PKM}

Tahapan pelaksanaan pelatihan PKM terlihat pada sebagai berikut :

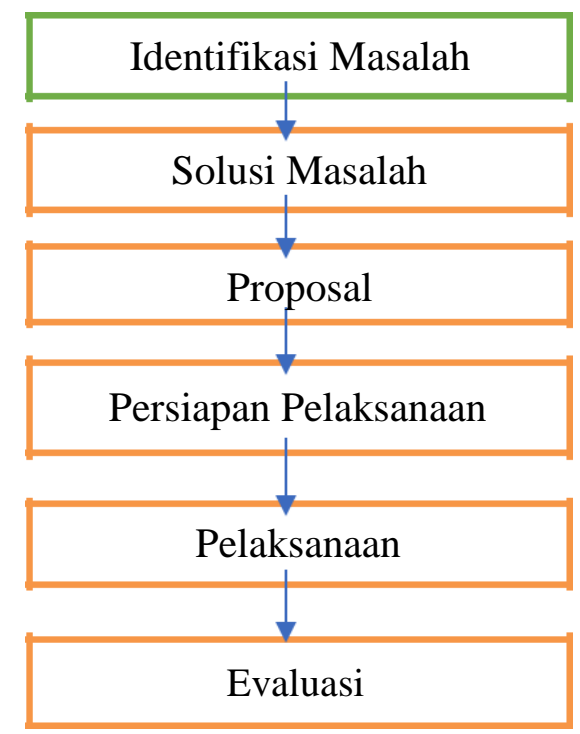

Gambar 3. Tahapan pelaksanaan PKM

Sumber : Penulis, 2020

Berdasarkan Gambar 3, tahapan pelaksanaan program pengabdian masyarakat (PKM) dibagi menjadi beberapa tahapan, meliputi :

Tahap Pertama: Melakukan studi mengenai masalah yang akan diberikan terkait pelatihan PKM.

Pada tahap ini, tim PKM mengadakan rapat pendahuluan untuk mengidentifikasi permasalahan pada Toko TODA. Hasil rapat pendahuluan adalah adanya gagasan untuk memberikan pelatihan 
pengendalian persediaan menggunakan metode Economic Order Quantity (EOQ). Hasil rapat tersebut kami koordinasikan dengan pihak UMKM dan gagasan tersebut diterima dengan baik.

Tahap Kedua : Melakukan survei kepada mitra terkait dan membuat surat pernyataan kesediaan mitra untuk dibina. Pada tahap ini tim melakukan survei kepada UMKM Toko TODA untuk mengetahui permasalahan yang dihadapi berkaitan dengan kinerja untuk mempersiapkan mencari solusi.

Tahap Ketiga: Mengajukan proposal

Pada tahap selanjutnya tim segera membuat proposal dan mengajukan sesuai dengan format dan batas waktu yang ditentukan.

Tahap Keempat: Melakukan persiapan pelaksanaan pelatihan.

Pada tahap ini tim melakukan persiapan untuk pelaksanaan pelatihan dengan mencari solusi dari permasalahan yang dihadapi mitra dan membuat modul.

Tahan Kelima: Melakukan pelatihan ke mitra.

Pada hari Jumat, 22 Mei 2020, tim melakukan pelatihan secara daring ke mitra Toko TODA untuk membuat pelatihan dan memberikan solusi atas permasalahan yang dihadapi mitra. Pelaksanaan pelatihan dilakukan tepat waktu sesuai dengan jadwal acara yang ditentukan dan berjalan dengan baik.

Tahap Keenam : Membuat laporan akhir dan artikel untuk siap dipublikasikan.

Setelah pelaksanaan pelatihan selesai, tim melakukan evaluasi singkat dan segera menyusun laporan akhir kegiatan. Evaluasi dilakukan melalui simulasi pada sampling perhitungan total biaya persediaan dari sample yang diambil terdapat potensi kehematan biaya jika dilaksanakan pengendalian persediaan barang dagang metode EOQ.

\section{Partisipasi Mitra}

Dalam rangka membina dan mengembangkan wawasan Unit Mikro Kecil Menengah (UMKM) dalam meningkatkan kinerja kegiatan usahanya, maka kegiatan dalam pengabdian kepada masyarakat dilakukan berupa pelatihan dengan tatap muka dan terbagi menjadi tiga sesi. Dikarenakan karena peraturan pemerintah untuk membatasi penularan virus covid 19, maka pelatihan dan pendampingan dilakukan secara daring.

Edukasi yang diberikan dengan pembatasan permasalahan sebagai berikut :

1. Penggunaan metode Economic Order Quantity (EOQ) yang dapat meminimumkan biaya persediaan barang dagang.

2. Penentuan frekuensi pemesanan barang dagang sehingga dapat meminimumkan biaya persediaan.

Partisipasi mitra dalam program PKM adalah ikut serta dalam berdiskusi, memberikan data-data historikal, dan menyampaikan target yang hendak dicapai. Target capaian dari pelatihan ini adalah Toko TODA dapat mengelola persediaan barang dagangnya sehingga tidak terjadi penumpukan barang terlalu banyak digudang yang secara tidak langsung dapat menurunkan biaya persediaan. Diharapkan setelah pelatihan selesai, maka Toko TODA dapat melakukan pengendalian persediaan barang dagang sehingga terjadi cost reduction.

Berikut Foto-foto kegiatan, pada saat kami melakukan pelatihan dan pendampingan secara daring kepada Toko TODA menggunakan aplikasi. 


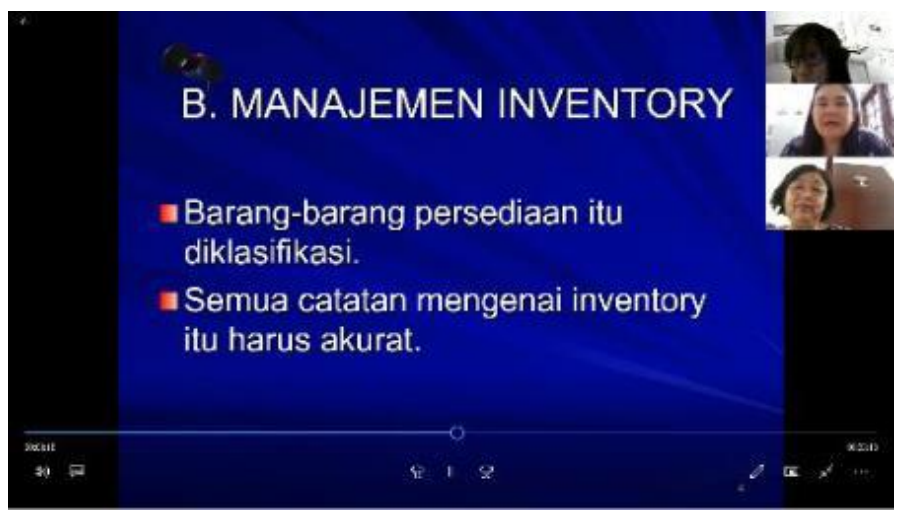

Gambar 4. Persiapan Pelaksanaan PKM secara daring Sumber : Penulis, 2020

Gambar 4. mendeskripsikan tim PKM mengadakan rapat secara daring sebagai persiapan dalam memberikan pelatihan kepada mitra melalui aplikasi zoom.
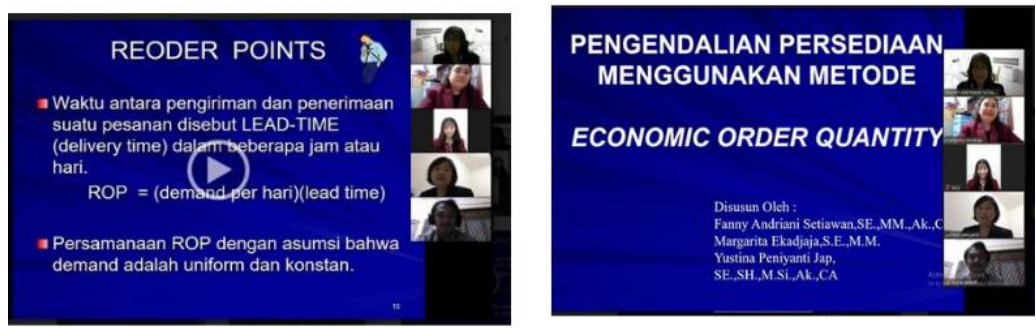

Gambar 5. Tim PKM memberikan pelatihan kepada mitra

Sumber : Penulis, 2020

Gambar 5. mendeskripsikan tim PKM memberikan pelatihan secara daring kepada mitra melalui aplikasi zoom. Materi pelatihan diberikan dalam bentuk video yang disertai dengan suara sehingga memudahkan dan menarik mitra Toko TODA untuk memahami materi pelatihan.

\section{HASIL DAN PEMBAHASAN}

Kegiatan PKM pada mitra Toko TODA telah selesai dilaksanakan pada tanggal 22 Mei 2020. Pelatihan dilakukan secara daring karena adanya pemberlakuan PSBB (Pembatasan Sosial Berskala Besar) akibat adanya pandemic Covid-19. Akibat terbatasnya sarana dan prasarana, maka jumlah partisipan dalam pelatihan sebanyak dua orang, yaitu pemilik dan satu orang sebagai perwakilan karyawan Toko TODA. Materi pelatihan diberikan dalam bentuk video interaktif berupa penjelasan mengenai pengendalian persediaan barang dagang melalui metode Economic Order Quantity (EOQ).

Pelatihan disesuaikan dengan permasalahan Toko TODA yaitu adanya keterlambatan pengiriman barang dari supplier, yang menyebabkan selama beberapa hari Toko TODA tidak dapat beroperasi maksimal. Di sisi lain Toko TODA juga pernah mengalami kelebihan persediaan barang dagang, sehingga perusahaan melakukan pemborosan akibat kelebihan persediaan yang dilakukan karena menambah biaya penyimpanan persediaan di gudang. 
Dalam pelatihan dilakukan pengenalan mengenai manajemen persediaan dan pemahaman mengenai komponen biaya yang dapat mempengaruhi besaran biaya persediaan dan metode pengendalian persediaan yang dapat meminimumkan biaya persediaan. Dengan adanya pengendalian persediaan barang dagang ini, maka secara langsung dapat mempengaruhi total biaya persediaan.

Agar biaya persediaan barang dagang Toko TODA tidak terlalu besar, maka Toko TODA harus menentukan jumlah unit yang optimum dengan biaya yang paling ekonomis. Salah satu metode pengelolaan persediaan barang dagang yang sesuai adalah metode Economic Order Quantity (EOQ).

Metode EOQ berasumsi bahwa pembelian suatu persediaan barang dagang akan ekonomis jika biaya simpan sama besarnya dengan biaya pemesanan (order). Dengan menggunakan data kartu stock dan laporan bulanan pembelian persediaan barang dagang dapat diketahui jumlah rata-rata persediaan barang dagang yang dibutuhkan dan frekwensi pemesanan persediaan barang dagang tersebut selama satu tahun. Perhitungan EOQ menurut Jay Heizer, et al. (2017) yaitu:

$$
\text { EOQ atau } \mathrm{Q}^{2 *}=2 \quad \mathrm{~S} \text { : }
$$

Frekwensi pemesanan barang $=\mathrm{D}: \mathrm{Q}^{*}$

Dimana:

$\mathrm{Q}=$ Jumlah unit per pesanan

$\mathrm{Q}^{*}=$ Jumlah optimum unit per pesanan

$\mathrm{D}=$ Penggunaan atau permintaan permintaan tahunan dalam unit

$\mathrm{S}=$ Biaya pemesanan untuk setiap pesanan

$\mathrm{H}=$ Biaya penyimpanan per unit per tahun

Dalam pelatihan juga dilakukan simulasi perhitungan persedaiaan barang dagang Toko TODA dengan mengambil beberapa sampel barang dagang mitra. Hasil simulasi perhitungan persediaan barang dagang Toko TODA berdasarkan data yang dikumpulkan oleh mitra pada Tabel 1.

Tabel 1. Hasil Perhitungan Persediaan Barang Dagang Toko Toda Menggunakan EOQ

\begin{tabular}{lccc}
\hline Nama Barang & Jumlah Kebutuhan Bahan 1 tahun & EOQ & Frekwensi Pemesanan barang \\
\hline Mesran 40 & 8295 & 1185 & 7 \\
\hline Mesran Super & 2590 & 370 & 7 \\
\hline Meditran S40 & 4293 & 477 & 9 \\
\hline Prima XP 20W 50 & 3448 & 431 & 8 \\
\hline Meditran SX 15W 40 & 1030 & 206 & 5 \\
\hline
\end{tabular}

Sumber : Toko Toda, 2020

Tabel 1. menunjukan bahwa pemesanan barang Mesran 40 dikatakan ekonomis jika setiap pemesanan sebesar 1185 unit. Dengan jumlah kebutuhan bahan selama 1 tahun adalah 8295 unit dan setiap kali pesan sebanyak 1185 unit, maka frekwensi pemesanan barang selama 1 
tahun adalah 7 kali. Demikian selanjutnya berlaku pada persediaan barang dagang oli lainnya (mesran super, meditran S40, prima XP 20W 50, dan meditran SX 15W40.

Tabel 2. Perbandingan Total Biaya Persediaan Tanpa dan Dengan EOQ

\begin{tabular}{lccc}
\hline Nama Barang & Total Biaya Persediaan Tanpa EOQ & Total Biaya Persediaan Dengan E0Q & Selisih \\
\hline Mesran 40 & 2180000 & 1090000 & 1090000 \\
\hline Mesran Super & 365000 & 338000 & 27000 \\
\hline Meditran S40 & 471000 & 439000 & 32000 \\
\hline Prima XP 20W 50 & 425000 & 387000 & 38000 \\
\hline Meditran SX 15W 40 & 274000 & 245000 & 29000 \\
\hline
\end{tabular}

Sumber : Toko Toda

Tabel 2. menunjukkan bahwa perhitungan total biaya persediaan barang dagang selama 1 tahun Toko TODA menggunakan metode EOQ dapat jauh menghemat biaya dibandingkan total biaya persediaan barang dagang sebelum menggunakan metode EOQ. Total biaya persediaan merupakan total biaya simpan dan total biaya pesan dari persediaan barang dagang. Di mana besarnya total biaya pesan tergantung dengan jumlah frekwensi pemesanan barang selama 1 tahun.

Pihak Toko TODA mulai memahami pentingnya pengendalian persediaan barang dagang agar kegiatan bisnisnya dapat berjalan dengan baik. Usulan prosedur pembelian persediaan barang dagang diterima dan mulai dijalankan dengan pemantauan dari Tim PKM terkait. Di mana pada akhir sesi pelatihan, para peserta yang terdiri atas pemilik dan karyawannya dapat menentukan jumlah dan jadwal pengadaan barang dagang secara ekonomis yang pada akhirnya meminimumkan total biaya persediaan. Dengan mengikuti metode yang disampaikan dalam pelatihan, maka peserta dapat melakukan perhitungan dan analisa terhadap produk-produk barang dagang lainnya.

Dalam kegiatan PKM ini, partisipasi mitra adalah dengan ikut serta dalam berdiskusi, memberikan data-data historikal, dan mencoba untuk melakukan simulasi perhitungan barang dagang pada produk-produk barang dagang lainnya. Luaran dari kegiatan PKM ini adalah mitra dapat mengetahui cara menghitung total biaya persediaan secara tepat, menentukan besarnya pemesanan barang dagang secara ekonomis melalui metode EOQ, dan menentukan jumlah frekwensi pemesanan barang dagang secara ekonomis dalam satu tahun sehingga tidak terjadi penumpukan barang dagang di gudang.

\section{KESIMPULAN DAN SARAN}

Kegiatan Pengabdian kepada Masyarakat (PKM) ini berjalan dengan baik walaupun ada sedikit gangguan dari sinyal wifi karena pelatihan diberikan dalam bentuk online. Pemberian modul dan video online mengenai manajemen persediaan sangat membantu sebagai solusi masalah Toko Toda dalam menentukan penjadwalan dan jumlah pengadaan barang dagang yang dibutuhkan untuk menjamin kelancaran usaha.

Pemilik Toko TODA mulai memahami pentingnya pengendalian persediaan barang dagang agar kegiatan bisnisnya dapat berjalan dengan baik. Usulan prosedur pembelian persediaan barang dagang diterima dan mulai dijalankan dengan pemantauan dari Tim PKM terkait. Berdasarkan hasil simulasi perhitungan dan diskusi menunjukkan bahwa penggunaan metode EOQ dalam mengendalikan persediaan barang dagang pada Toko Toda sangatlah efisien terlihat dari besarnya 
penghematan biaya yang diperoleh jika perhitungan total biaya persediaan menggunakan metode EOQ.

Mitra Toko TODA dapat menentukan jumlah frekwensi pemesanan barang dagang yang ekonomis sehingga tidak terjadi penumpukkan barang dagang di Gudang. Pada akhir sesi pelatihan, mitra Toko TODA dapat menentukan jumlah dan jadwal pengadaan barang dagang secara ekonomis yang pada akhirnya meminimumkan total biaya persediaan. Hal ini dilakukan mitra Toko TODA melalui simulasi perhitungan dan analisa terhadap produk-produk barang dagang lainnya.

Pihak Toko Toda menginginkan pelatihan lebih lanjut yang berguna dalam peningkatan kinerja usahanya seperti peningkatan mutu pelayanan, peningkatan penjualan, dan cara memotivasi tenaga kerjanya sehingga dapat melaksanakan pekerjaannya dengan baik.

\section{Ucapan Terima Kasih (Acknowledgement)}

Terima kasih kepada Lembaga Penelitian dan Pengabdian Kepada Masyarakat (LPPM UNTAR) yang telah mendanai kegiatan PKM ini. Terima kasih juga kepada Fakultas Ekonomi dan Bisnis Universitas Tarumanagara yang telah membantu dalam kegiatan administrasi program Pengabdian Kepada Masyarakat sehingga kegiatan PKM berjalan dengan lancar.

\section{REFERENSI}

Brigham, E. F., \& Houston, J. F. (2016). Fundamentals of Financial Management: Concine, Ninth Edition. Boston: Cengage Learning.https://doi.org/10.1017/CBO9780511790546.026.

Eugene F. Brigham and Joel F. Houston. (2015). Fundamentals of Financial Management. Boston: Cengage Learning. https://doi.org/10.1017/CBO9780511790546.026

Jay Heizer, Barry Render, Chuck Munson. (2017). Operations Management Sustainability and Supply Chain Management. England: Pearson Education.

Muryanti, Y. D., dan S. (2017). The Effect of Intelectual Capital Performance, Profitability , Leverage, Managerial Ownership, Institutional Ownership, and Independent Commissioner on The Disclosure of Intelectual Capital. Accounting Analysis Journal, Vol.6(1), pp.56-62 https://doi.org/ISSN 2252-6765.

Satria, A. (2016). Teori Persediaan (Pengertian, Tujuan, Fungsi, Jenis Dan Biaya Persediaan Menurut Para Ahli). Diakses pada 18 Mei 2017, dari www.materibelajar.id.

Tamodia, W. (2013). Evaluasi Penerapan Sistem Pengendalian Intern Untuk Persediaan Barang Dagangan Pada PT Laris Manis Utama Cabang Manado. Jurnal Riset Ekonomi, Manajemen, Bisnis Dan Akuntansi, Vol.1(3), pp.20-29.

Wahyudi, R. (2015). Analisis Pengendalian Persediaan Barang Berdasarkan Metode EOQ Di Toko Era Baru Samarinda. Ejournal Ilmu Admistrasi Bisnis, Vol.2(1), pp.162-173.

Wardhani, P. S. (2015). Perencanaan Dan Pengendalian Persediaan Dengan Metode EOQ. Jurnal Media Mahardika, Vol.13(3), pp.310-328.

Yuliana, C., \& Sudjana, N. (2016). Penerapan Model EOQ (Economic Order Quantity) Dalam Rangka Meminumkan Biaya Persediaan Bahan Baku (Studi Pada UD. Sumber Rejo Kandangan-Kediri). Jurnal Administrasi Bisnis S1 Universitas Brawijaya.Vol.36(1),pp.1-9. 